\title{
Analysis on the Status Quo and Construction Problems of Domestic Urban Civil Air Defense Engineering System in China
}

\author{
Junzhang Chen ${ }^{1}$ and Yile Chen ${ }^{2} \square$ \\ ${ }^{1}$ Faculty of Innovation and Design, City University of Macau, Avenida Padre Tomás Pereira Taipa,Macau SAR, China \\ ${ }^{2}$ Faculty of Humanities and Arts, Macau University of Science and Technology, Avenida Wai Long Taipa, Macau SAR,China
}

$\square$ Corresponding Author: Yile Chen, E-mail: 2009853gat30001@student.must.edu.mo

ARTICLE INFORMATION ABSTRACT

Received: 19 October 2021

Accepted: 20 November 2021

Published: 31 December 2021

DOI: 10.32996/jmcie.2021.2.2.8

\section{KEYWORDS}

Urban civil air defense, engineering city, development city, people urban construction, functional departments
As the urbanization process in developing countries continues to accelerate, although my country has achieved significant results in planning and construction, there are still many problems. For example, the rate of urban green space decreases with the continuous increase of urban buildings. Therefore, the domestic urban underground civil air defence Engineering construction is in a very important position at this stage, and our development goals must be shifted from above ground to underground. This article analyzes the general situation of the domestic civil air defence engineering system, expounds on the current situation and existing problems of my country's urban civil air defence engineering system, which has an important influence on the development of my country's cities. Functional departments must take into account the various functions of civil air defence projects and put people's safety first. At the same time, firefighters should also improve their professionalism, leadership and organizational skills, and evacuate people when encountering danger and arrange for them to take refuge in designated locations. The technicians in the relevant departments in the city need to use scientific and technological means to mix the urban network system in series and parallel so that the various structures of the urban network system are unified and interact with each other. When a disaster strikes, it can protect the safety of the people and reduce the economic loss of the city. Reduce to the lowest level to maximize benefits.

\section{Introduction}

\subsection{Research background}

Since London, a developed country built the world's first subway in 1863, the construction and development of underground space in foreign countries have continued; my country formulated the "long-term preparation and key construction" policy in 1954 and only considered the need for combat readiness; it was determined in 1990 The policy of "long-term adherence to peacetime and wartime integration, comprehensive planning, and key construction" is proposed, and "vigorously develop peacetime and wartime integration, and maximize social and economic benefits under the premise of ensuring the benefits of combat readiness." With the continuous acceleration of social urbanization in developed and developing countries, civil air defence projects in cities have also increased. Although it is in a peaceful age, relevant units of functional departments should also pay attention to and do a good job in urbanization. The preparations for the combat readiness of civil air defence projects and the underground air defence design should also be closely linked to the lifeline of the city, and it should also be integrated and developed with urban infrastructure, transportation, and economic construction.

When the war comes, the underground civil air defence project will more effectively avoid the enemy's surprise attack, preserve combat power, and become an important guarantee for safeguarding the safety of people's lives and property, laying a good foundation for the entire city to proceed in a more orderly manner.

Copyright: (C) 2021 the Author(s). This article is an open access article distributed under the terms and conditions of the Creative Commons Attribution (CC-BY) 4.0 license (https://creativecommons.org/licenses/by/4.0/). Published by Al-Kindi Centre for Research and Development, London, United Kingdom. 


\subsection{Research purpose and significance}

With the continuous acceleration of social urbanization in developing countries, civil air defence projects in cities are increasing. Although it is in a peaceful age, we must also pay attention to and prepare for civil air defence projects in cities. At the same time, underground The civil air defence design of China should also be closely connected with the lifeline of the city, and it should also be integrated and developed with urban infrastructure, transportation, and economical construction. Looking at the overall situation, although my country's urban civil air defence engineering construction has achieved significant results, there are still many problems in urban planning and construction, publicity, and civic awareness.

This research discusses the actual case study and social value of domestic urban civil air defence engineering system, expounds on the shortcomings of domestic urban civil air defence system construction, and then comes up with an effective and feasible method to solve the Chinese urban civil air defence problems.

\subsection{Research methods}

When the war came, due to the fragility of the urban network system, the urban economic chain and power supply, water supply and heating systems were destroyed. Therefore, for the urban network system that affects the whole body, the technicians of the relevant departments in the city use scientific and technological means to merge the various serial systems in the city. Only by assuming their respective roles and connecting with each other can the damage to the city's interests be minimized in the war.

Smart, civil air defence is not limited to the self-improvement of civil air defence systems, but must adapt to urban development, focus on the future, take information technology as the forerunner, use scientific and technological means to decompose intelligent civil air defence plans and project arrangements, and develop new ideas in specific project arrangements. Combining the old projects with corresponding adjustments and improvements and combining them with new projects, intelligent air defence needs to stand firm, improve core functions, form a system of its own, and reduce dependence on the outside world.

This research is conducted by consulting domestic journal articles, research reports, and related policies and cultures of provinces and cities on civil air defence and construction in China, sorting them, summarizing them, and combining them with related theories. Analyze the problems existing in the construction of civil air defence engineering systems in domestic cities, and propose corresponding solutions.

\section{The development of domestic research on civil air defence engineering}

Since the 1950s, due to the unstable internal environment of the country, cities in our country have begun to build air defence projects. The vast majority of air defence projects are designed and built for combat readiness, so their function and value will appear to be relatively simple. At the same time, there is a disconnect between air defence projects and urban construction, and they have not been used to the maximum.

After the end of the Korean War, China used the experience of the Moscow Metro's role as an air-raid shelter and military command post in defence of Moscow and began preparations for the construction of Beijing's subway. Beijing Railway Station-DongdanZhongshan Park-Shijingshan and Longtan-Tiananmen-Xisi-Xizhimen-Summer Palace. Although there is no small difference from the actual situation of Beijing Metro Line 1 and Line 2 today, the engineering idea of connecting the political center, the transportation hub and the mountains in the northwest is basically determined. In 1969, the first phase of Beijing Metro Line 1 was finally completed and opened to traffic. In 1971, the Beijing Subway began to receive passengers with letters of introduction from the unit. Strictly speaking, these passengers are "spectators" visiting Beijing's civil defence construction. This subway only began to take on the transportation task after the cancellation of the system of purchasing tickets based on letters of introduction in 1972.

After 1978, the original air defence combat readiness function of my country's urban civil air defence engineering has been further expanded, and the concept of building a civil air defence engineering system that combines peacetime and warfare has been put forward. The value and commercial value of urban civil air defence projects in wars have also been further effectively utilized. The relevant data shows that the development goals of Qingdao's underground air defence projects are from the first stage to 2020, which is the short-term and long-term goals of this plan. It is to improve land-use efficiency, expand urban space capacity, and establish an urban safety guarantee system; the second phase to 2050 is the long-term vision of this plan. The goal is to fully realize the underground urban infrastructure and greatly improve the quality of urban life.

There is also the Beijing Metro Line 2 platform, the underground parking lot of Shanghai People's Square, the underground shopping mall of Zhengzhou Railway Station Square (Figure 1), the underground city of Shenyang Beixin Passenger Station and Chengdu Xiyuheyan Street. In addition to the commercial value of the underground space, there is also a design to create tourist 
attractions connected to the ground business district. The development of the commercial use value of these civil air defence projects has brought investors. Economic costs have also brought social benefits to relevant functional units.

The most famous is undoubtedly the Formosa Boulevard MRT Station in Kaohsiung City, Taiwan Province, China (Figure 2). The dome hall of Formosa Boulevard Station, the intersection of the red and orange lines of the Kaohsiung MRT, was created by the world-renowned artist Narcissus Quagliata (Master Narcissus)2. By integrating various glass art classics and production techniques, the world's largest single piece has been created. The glass public art work, "The Dome of Light", brings a new aesthetic atmosphere to the Hong Kong capital and makes Gaojie Formosa Boulevard an emerging tourist attraction. "The Dome of Light" took nearly 4 years and was completed under the supervision of Master Narcissus himself and was shipped to Taiwan by Germany for installation. The theme of the dome creation is divided into 4 major sections, and the overall creation in a clockwise direction is as follows: water-the birth of life, soil-prosperity and growth, light-creative spirit, fire-destruction and rebirth, four major themes, telling people's stories. This large-scale public art with "love and tolerance" as its main axis has a diameter of 30 meters and a dome area of 660 square meters. The artisans draw a 1:1 lead line draft personally based on the master Narcissus. A line (lead bar) presents the new look of mosaic glass under the accumulation of thousands of years of tradition. It is currently the world's largest classic masterpiece of mosaic glass art, on the ground of Formosa Boulevard MRT Station, Kaohsiung's most famous South China tourist business district. There are all kinds of daily necessities, clothing, snacks, groceries, etc., and because most of them are mainly women's products and clothing, it is also called Ladies' Street. Therefore, this is also a good example of the combination of sightseeing and artistic attractions as the core and underground space to connect the business district.

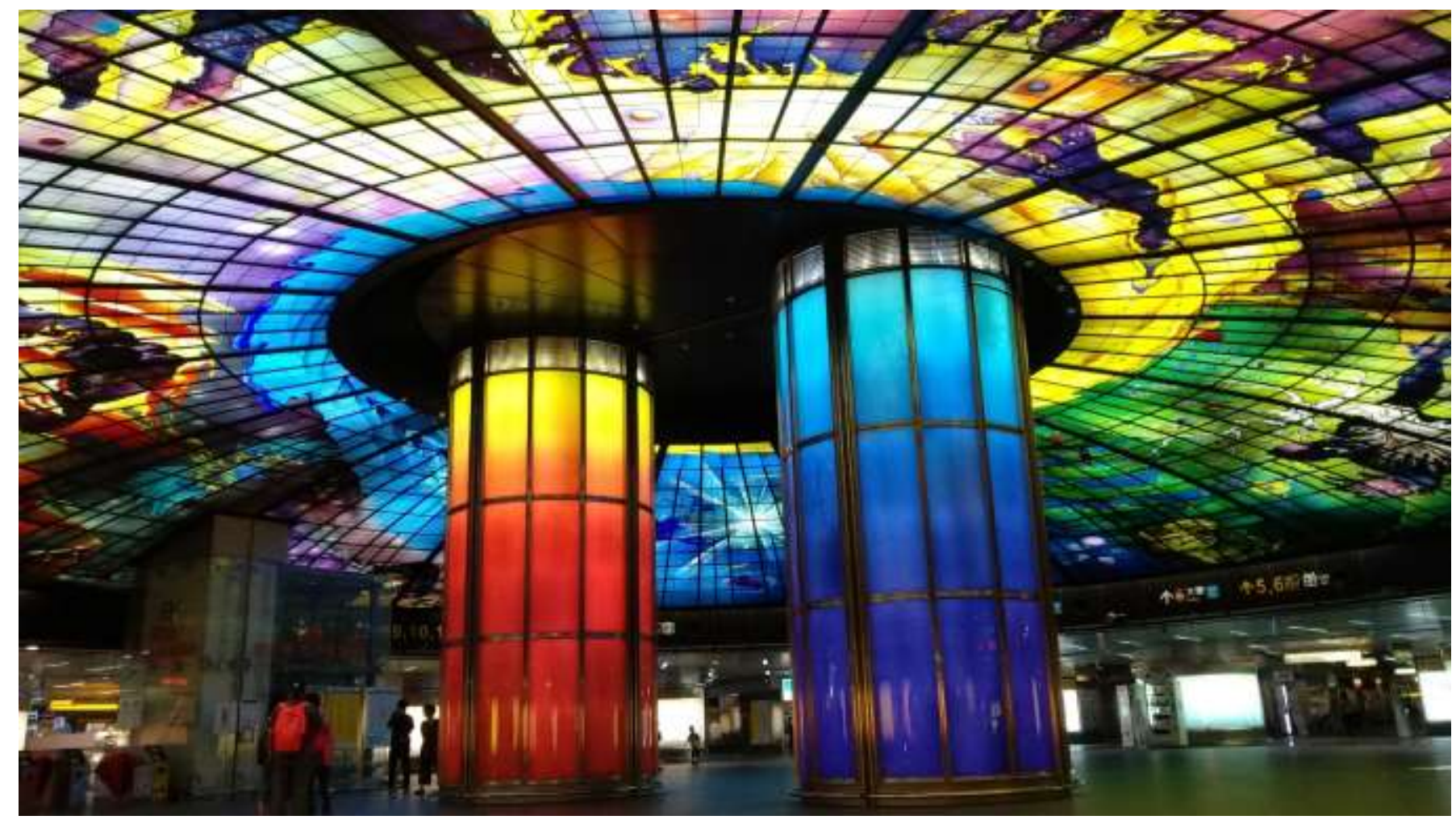

Figure 1. Formosa MRT Station in Kaohsiung City, Taiwan Province, China (Image Source: Photographed by the author)

In cities with frequent typhoons on the coast of China, such as Macau, the focus of civil air defence projects is to evacuate residents in low-lying areas when typhoon signal No. 8 or above is hoisted. There are currently 17 shelters, 4 assembly points and emergency evacuation stops in Macau(Figure 4). It is divided into level 1 typhoon avoidance: drinking water, biscuits, and cup noodles will be provided during the period. And second-level evacuation hazard: the center will provide basic materials such as drinking water, dry food, mattresses, sanitary equipment, radios, televisions, charging facilities, and auxiliary equipment. Some centres have barrier-free facilities. In addition to the safe-haven center, the Macau Police Headquarters has further expanded its information release channels and jointly launched the "Macao Civil Defense Information" mobile application developed in cooperation with the Public Security Institute of Tsinghua University with the Security Forces Affairs Bureau(Figure 3). Citizens can receive all kinds of civil defence information in real-time, including weather, various shelters, gathering points for people in need, locations of

${ }^{2}$ Narcissus Quagliata: Narcissus Quagliata is considered one of the most significant contemporary artists in glass. He has defined a new pathway for stained glass art and is best known for his spectacular artworks in public spaces, which have drawn worldwide attention. 
emergency stay gathering points, the number of users, and civil defence information such as disaster avoidance and disaster prevention. And users who use this civil defence app can also quickly call for help through the program, which is also equipped with a voice broadcast function for those in need. The main domestic underground air defence construction in my country is shown in Table 1.

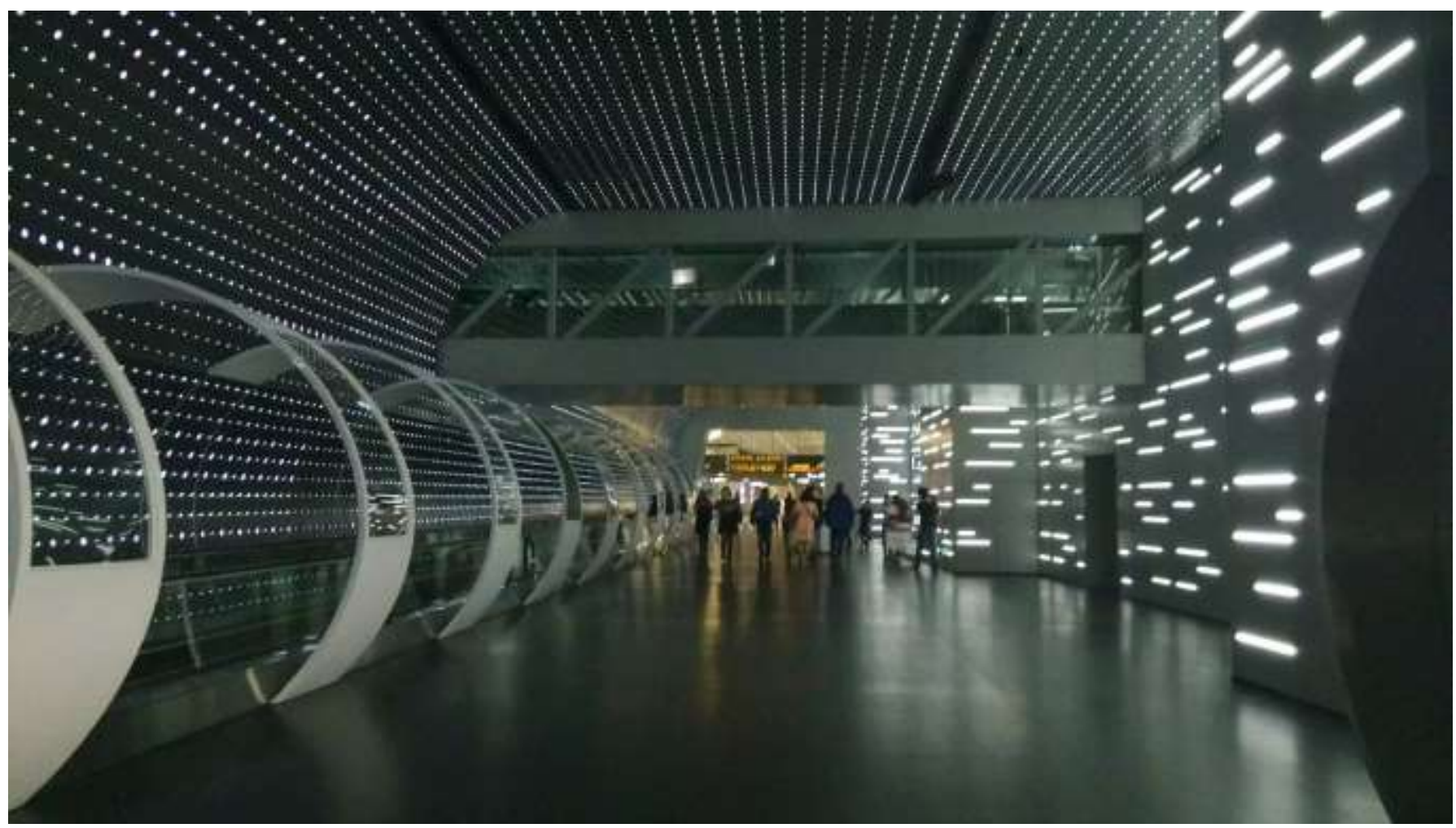

Figure 2. Guangzhou urban underground complex space (Image Source: Photographed by the author)
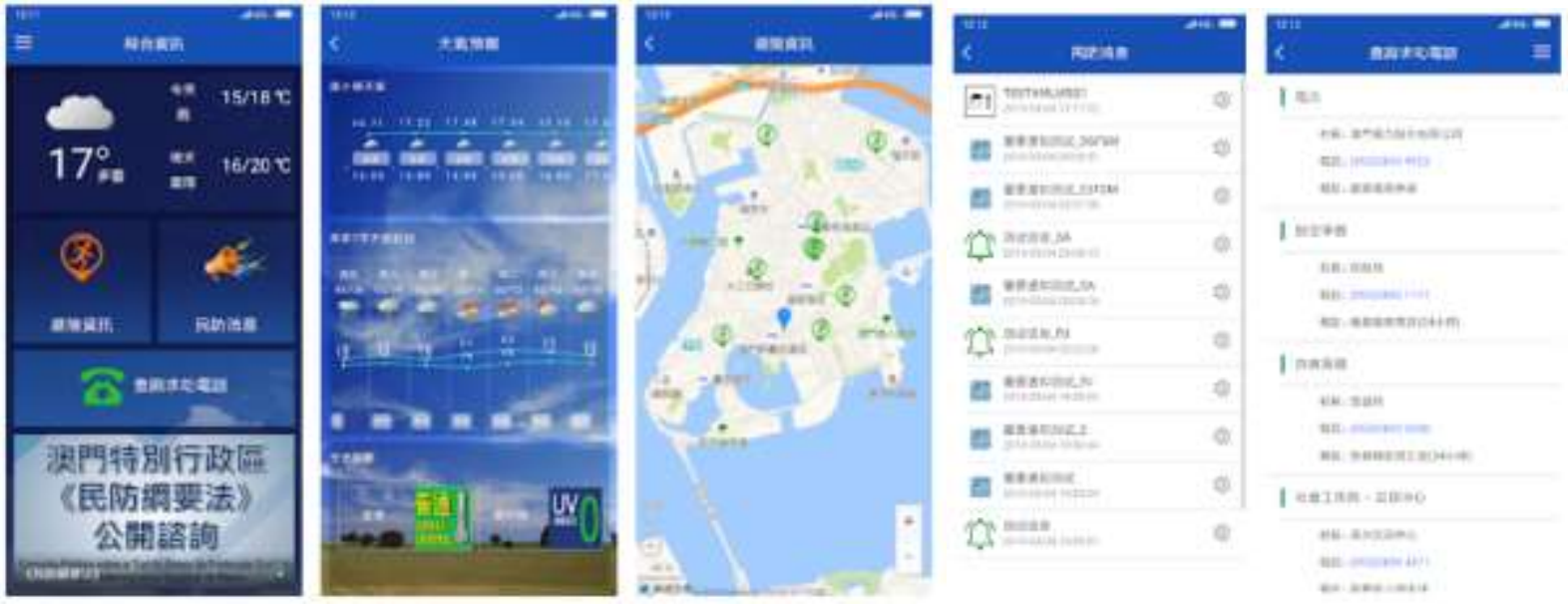

Figure 3. "Macao Civil Defense Information" mobile application (Image Source: Screenshot from the app) 

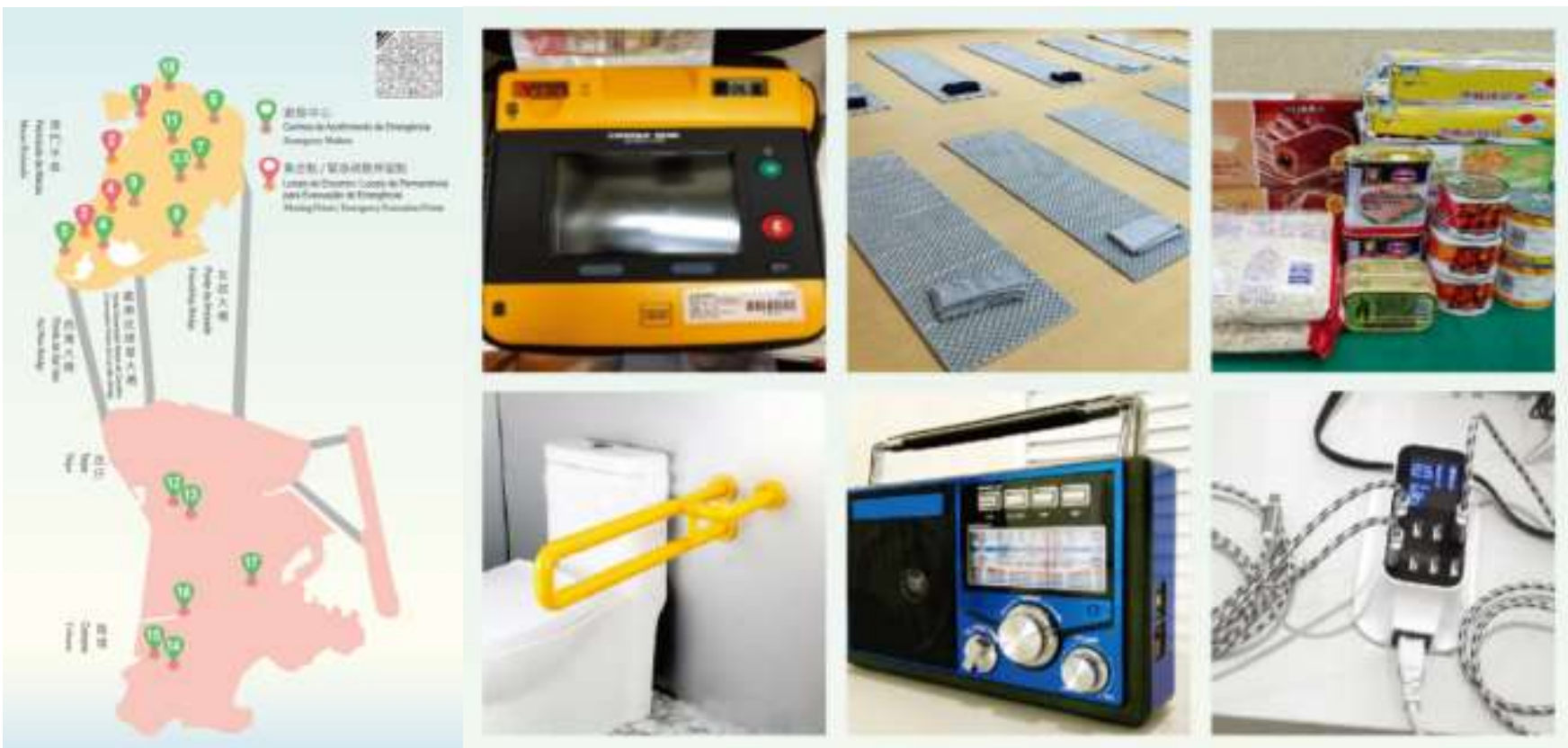

Figure 4. Distribution map of safe haven centres in Macau (Image Source: Social Work Bureau of Macau Special Administrative Region Government)

Tabel 1. Main domestic underground air defence construction

\begin{tabular}{|c|c|c|c|}
\hline Project name & Location & Features & Stage \\
\hline $\begin{array}{c}\text { Underground Oil Depot in } \\
\text { Bussuri Military Cultural } \\
\text { Tourism Zone }\end{array}$ & $\begin{array}{c}\text { Deep Mountains of Northern } \\
\text { Xinjiang }\end{array}$ & $\begin{array}{l}\text { Aviation gasoline and liquid gas, } \\
\text { etc., in order to quickly receive } \\
\text { imported crude oil during wartime } \\
\text { and distribute it to military } \\
\text { machinery to store crude oil and } \\
\text { heavy fuel oil. }\end{array}$ & Construction completed \\
\hline $\begin{array}{c}\text { Chengdu No. } 1 \text { Air-raid } \\
\text { Shelter }\end{array}$ & Chengdu Xiyuheyan Street & $\begin{array}{l}\text { The advantage of a cool spot for } \\
\text { citizens is that it provides cool tea } \\
\text { for the city residents and provides } \\
\text { books and newspapers outside the } \\
\text { emergency medical kit, and puts a } \\
\text { large amount of civil air defence } \\
\text { knowledge and disaster prevention } \\
\text { knowledge publicity data for the } \\
\text { citizens to read. }\end{array}$ & Construction completed \\
\hline $\begin{array}{l}\text { Guangzhou Underground } \\
\text { Complex }\end{array}$ & Guangzhou City & $\begin{array}{l}\text { A multi-functional underground } \\
\text { complex integrating large-scale } \\
\text { commerce, citizen entertainment } \\
\text { and subway transfers, forming an } \\
\text { organic combination with large } \\
\text { squares on the ground, bus, train } \\
\text { passenger stations, and street } \\
\text { crossing tunnels }\end{array}$ & Construction completed \\
\hline $\begin{array}{l}\text { Shenyang Station Square } \\
\text { Underground Complex }\end{array}$ & $\begin{array}{c}\text { The intersection of Zhonghua } \\
\text { Road and Shengli Street }\end{array}$ & $\begin{array}{l}\text { An underground garage is set up } \\
\text { under the underground mall to } \\
\text { solve the parking problem in front } \\
\text { of the station and the square, } \\
\text { allowing passengers to shop in the } \\
\text { underground mall }\end{array}$ & Construction completed \\
\hline Shanghai People's Square & Huangpu District, Shanghai & $\begin{array}{l}\text { Underground shopping malls, } \\
\text { underground garages and streets }\end{array}$ & Construction completed \\
\hline
\end{tabular}




\begin{tabular}{|c|c|c|c|}
\hline Project name & Location & Features & Stage \\
\hline & & $\begin{array}{l}\text { form a complex located in a } \\
\text { prosperous area in the center of } \\
\text { Shanghai. It combines squares, } \\
\text { greenery and roads to build } \\
\text { comprehensive commercial } \\
\text { facilities, integrating commercial, } \\
\text { cultural and entertainment parking } \\
\text { lots and public facilities. }\end{array}$ & \\
\hline $\begin{array}{l}\text { Bell and Drum Tower of } \\
\text { Xi'an City }\end{array}$ & $\begin{array}{c}\text { Xi'an City Center, Shaanxi } \\
\text { Province }\end{array}$ & $\begin{array}{l}\text { Historical and cultural cities, } \\
\text { historical locations of cities, and } \\
\text { scenic spots are built to protect the } \\
\text { traditional historical features and } \\
\text { natural landscapes on the ground } \\
\text { from damage. }\end{array}$ & Construction completed \\
\hline $\begin{array}{l}\text { Civil Air Defense } \\
\text { Underground Street, 2nd } \\
\text { Floor, Datong Road, } \\
\text { Zhengzhou City }\end{array}$ & $\begin{array}{c}\text { Erqi District, Zhengzhou City } \\
\text { Center }\end{array}$ & $\begin{array}{l}\text { Datong Road is east-west. The } \\
\text { roadside brings together a trade } \\
\text { city, clothing city, clothing } \\
\text { management, clothing plaza, and } \\
\text { hotels, forming a clothing-oriented } \\
\text { wholesale center, and has a } \\
\text { reputation as a clothing city. There } \\
\text { are Zhengzhou Railway Station and } \\
\text { cars nearby. The passenger station } \\
\text { and Metro Line } 1 \text { have a large flow } \\
\text { of people and goods and are the } \\
\text { main commercial areas. When a } \\
\text { war breaks out, it has the function } \\
\text { of facilitating people's life in } \\
\text { wartime and sheltering. }\end{array}$ & Completion of planning \\
\hline $\begin{array}{c}\text { Harbin Underground } \\
\text { Street }\end{array}$ & Dalian Railway Station Square & $\begin{array}{l}\text { Several underground commercial } \\
\text { streets are connected to the city, } \\
\text { forming an underground city of } \\
250,000 \text { square meters. My } \\
\text { country's largest underground } \\
\text { complex, "Never Sleeping City", } \\
\text { was completed and put into use } \\
\text { this year, with five-story } \\
\text { underground garages and } \\
\text { shopping malls for cultural } \\
\text { entertainment. Center, catering } \\
\text { center, etc. Its construction area } \\
\text { reaches } 147,000 \text { square meters. }\end{array}$ & Construction completed \\
\hline Macau Safe Haven Center & Macau city & $\begin{array}{l}\text { focus on civil air defence projects is } \\
\text { to evacuate residents in low-lying } \\
\text { areas when typhoon signal No. } 8 \text { or } \\
\text { above is hoisted }\end{array}$ & Construction completed \\
\hline $\begin{array}{c}\text { Taiwan Underground } \\
\text { Space }\end{array}$ & $\begin{array}{c}\text { Formosa MRT Station in } \\
\text { Kaohsiung City }\end{array}$ & $\begin{array}{l}\text { Sightseeing and artistic attractions } \\
\text { as the core, combined with the } \\
\text { underground space to connect the } \\
\text { business district, all kinds of daily } \\
\text { necessities, clothing, snacks, } \\
\text { groceries, etc., as well as women's } \\
\text { products and clothing }\end{array}$ & Construction completed \\
\hline
\end{tabular}




\section{Unreasonable Planning Of Urban Civil Air Defense Engineering System}

China is now in an era of peace. The level of the city is constantly developing, the economic foundation is also very solid, and it has also had a very beneficial impact on the superstructure. People nowadays have increasingly blurred the concept of urban civil air defence engineering systems. Most people do not have an awareness of civil air defence at all. The relevant administrative agencies in some large cities and some small cities are relatively unfamiliar with the concept of urban civil air defence, so the emphasis on urban civil air defence is also very low. The theories developed by some urban civil air defence projects are out of line. In fact, it includes the phenomenon of unreasonable planning, insufficient funds for small-scale urban planning, and the inconsistent pace of civil air defence system planning and overall urban planning.

\subsection{Unreasonable planning of urban civil air defence engineering system}

The civil air defence project in a city is a relatively large-scale project in the construction of urban infrastructure because it involves a wide range of planning, small is closely connected with the lifeline of the city itself, and large is also closely connected with neighbouring cities. Therefore, it is an important part of the urban planning infrastructure construction and maintenance that belongs to a branch of the entire urban planning and design.

The problem facing our country now is that many cities generally lack experience in constructing and maintaining urban infrastructure, and planners have not considered the important impact of future urban development on the urban civil air defence engineering system. The urban civil air defence projects that have been built are repaired and repaired, but there is no planning and design for long-term maintenance programs. There are even some cities that do not combine theory with reality in the planning of civil air defence infrastructure construction, resulting in unreasonable phenomena in the planning of civil air defence projects in some cities. Civil air defence projects between adjacent cities appear to be mutually opposed, contradictory and inconsistent. The phenomenon caused by the new urban civil air defence engineering system pipeline conflicts with the old urban air defence engineering system pipeline and ultimately requires re-planning and design, wasting a lot of manpower, material and financial resources. In the urban planning process, some cities did not carry out peace and war unification, combined peace and war, and the ground and underground passages were not connected, or there was a development trend of independent government, resulting in serious disconnection. This is also due to the relevant urban planning departments. There were unreasonable phenomena in the planning, which were not resolved at the time. The responsible persons of some construction units were negligent in the review stage and did not further think about the civil air defence plan planned by the planning company and directly submitted for approval, which eventually led to the construction.

\subsection{Lack of funds for the construction of urban civil air defence engineering systems}

Due to the very wide construction scope, a huge amount of construction, and very long time-consuming construction of civil air defence projects in cities, the cost recovery period of the construction is very long, which makes investors feel that they have not benefited in a short period of time. Some investors are unwilling to invest in the construction of urban civil air defence projects. As a result, there are a lot of difficulties in raising funds for the construction. In our country, functional units' fundraising of urban civil air defence construction is led and undertaken. Funds are allocated for construction. For large cities, their overall development speed is fast, urbanization is also proceeding early, and the economic growth rate is much faster than that of ordinary cities. Therefore, the pressure on urban civil air defence engineering construction investment is relatively small.

But for small cities, because the process of urbanization is relatively late, compared with large cities, the economic growth rate is also slower, and there are many problems in raising funds, even infrastructure. Raising the cost of repairs and maintenance has also caused great difficulties, not to mention the city's long-term planning. Looking for relevant design companies and planning institutes to plan the plans for the future urban air defence facilities also requires a sum of funds. Different cities in the same country are out of sync, unbalanced, and inconsistent due to development speed. As a result, the construction of civil air defence engineering systems in different cities is unsynchronized and ununified due to the shortage of funds, and the development is uneven.

\subsection{Functional units are not fully aware of the construction of urban civil air defence projects, and more and more people are not aware of it}

Some cities lack awareness of the construction and maintenance of the urban civil air defence engineering system, and the relevant departments do not have a comprehensive understanding. They believe that we are now in a peaceful age, and there will be neither war nor natural disasters. The maintenance and construction of the system and the planning of the impact of urban development on civil air defence in the next few decades and the subsequent review and approval of the design plan also require a large number of funds. Therefore, functional departments in some small cities feel that there is no need to do so. Waste of funds In these aspects, maintenance and construction also require a lot of time, manpower, material, and financial resources. These cities do not need to build and maintain civil air defence projects, and even some cities do not feel that civil air defence projects have any positive impact on the city. 
With the acceleration of my country's urbanization process, the density of buildings on the ground has gradually increased. They have not considered that the ground and the underground are equally important. They try to save the space on the ground to develop green space and vigorously develop the underground space, even if it is a small city. With the passage of time, when the population of big cities becomes saturated, the pressure of transportation and the social economy will gradually increase, and people related to big cities will also move to small cities for development, which will have an impact on small cities. That is, the population of small cities will gradually increase, so administrative departments must also consider the future development of small cities and make better use of civil air defence projects to solve many difficult problems in the future.

In addition, more and more people in the city have a low awareness of being attributed to the urban air defence system. Most people living in this city do not know where the city's air defence system is or which facilities belong to the city's air defence system. They are in underground passages. Littering, urinating and urinating at will, and found that some underground infrastructures are ageing and have not been reported to relevant departments. It is not a matter of hanging up high. Some want to reflect but don't know what channels to report through, and even reflect that relevant departments do not have this consciousness to pay attention.

\section{Countermeasures To The Civil Air Defense Problems In Domestic Cities 4.1 Reasonably design and plan the design of urban civil air defence projects}

The relevant areas of our country should rationally design and plan the construction plan of the urban civil air defence project. First, the air defence basement is assessed as unqualified. The construction unit should make rectification according to the opinions of the civil air defence department and then report to the civil air defence department for re-inspection until qualified. Otherwise, the entire project may not be rated as an excellent project, may not be delivered for use, and may not apply for a real estate certificate.

Secondly, for future urban planning, corresponding planning plans should be formulated, and city research should be fully done to prevent conflicts between the urban civil air defence project and the neighbouring city civil air defence project planning, and the theory should be combined with reality, and the urban civil air defence system planning should strive for Coordinate with the overall development pace of the city planning. Then the relevant staff in the urban civil air defence system planning must be strictly trained, and the designed construction drawings must be reviewed by professionals. During the review process, they must not be careless. The drawings must be accurately reviewed without a trace. The problematic drawings must be strictly returned and recorrected during the verification process. Unreasonable points found during the construction process must be corrected and perfected in a timely manner. When necessary, they must be reported to the relevant supervision unit for verification to ensure that there is nothing wrong.

\subsection{Establish a commercial financing development system to attract more investment from developers, and at the same time achieve peace and war}

Urban civil air defence engineering system planning must properly solve the problem of insufficient funds. In addition to government funding for large-scale confidential urban air defence projects, commercial financing systems should be established for other cities. In addition to modern civil air defence projects, attention must be paid to combat readiness. In addition to functions that can come in handy during a war, we must also pay attention to the use of the commercial value it brings to attract more investors to invest and strive for higher benefits.

For second-and third-tier cities that have a gap in the development status of first-tier cities or even cities that are not ranked, they can be appropriately reported to the provincial level so that the provincial level can plan and deploy, and the problem of insufficient funds can also be applied to the higher level for investment. Developed cities can also give appropriate economic investment to second-and third-tier cities to promote the future development of second-and third-tier cities and some more backward cities.

At the same time, cities whose development status is not optimistic can also seek help from neighbouring cities, do related trade exchanges, and strive to get closer to first-tier cities so as to achieve a balanced, unified and synchronized development as soon as possible. Relevant cities are also working hard to make the civil air defence system in the city have the function of combining peace and war. The combination of peace and war refers to the software and hardware facilities of all aspects of civil air defence construction, which can be used in society during peacetime without affecting the ability of air defence. It can directly become a part of urban construction and economic construction and produce good social and economic benefits. This kind of behaviour based on combat readiness, focusing on peacetime, serving the society and benefiting the people, can only inspire the investment enthusiasm of people in the society if the civil air defence project is unified between peace and war. 


\subsection{Strengthen the concept of urban air defence construction and encourage citizens to participate in urban air defence construction}

For the lack of understanding of the urban civil air defence engineering system, we must first strengthen the concept of urban civil air defence construction. Only by strengthening the concept of urban civil air defence construction can the masses and officials of relevant agencies understand the importance of building and improving urban civil air defence.

The provincial party committee should also regularly convene relevant meetings on the construction of urban civil air defence and lead the city-level party members and cadres to realize the necessity of urban civil air defence construction and repair so that the work of civil air defence construction can be promoted more effectively. Make a speech, let the leaders of the agency understand the ideas of the party members through the speech, and then convey to them the study guidance recommendations issued by the provincial party committee.

At the same time, let the personnel of the agencies and units increase the publicity of the civil air defence in the city, visit the citizens on the spot, and let the citizens better understand the role of the civil air defence in the war. Encourage them to report to the relevant departments in time when they find that the civil air defence system is damaged. The civil air defence department should not only conduct important publicity through newspapers and media and other social networking sites, but also publicize through public accounts, Weibo, etc., to spread the construction of urban civil air defence to various units and schools, and regularly communicate to the staff and the staff of the unit. The school's students are trained to strengthen their ideological awareness and can also spread the urban civil air defence to various communities, train the residents of the community, and hold prize-winning questions and answers so that people can gain knowledge of civil air defence at the same time.

\subsection{Functional departments should issue relevant policies to ensure the unification of urban above-ground and underground planning}

It should be considered from the overall aspect of the city. The planning of the urban underground air defence engineering system at this stage is the same as that on the ground. It requires long-term plans and goals. Starting from the relevant city's functional departments determining the urban air defence system planning task book, give the city The planning unit issued a task. The relevant planning unit first collected data for the city and assigned the relevant research team to conduct a preliminary investigation of the city's original civil air defence planning and met to discuss, analyze, and determine the preliminary design plan. Eventually, in the discussion process with the functional departments, I learned about the future planning goals of the administrative unit and kept consistent with the thinking of the government and higher-level organizations at all times. All departments should raise their awareness of the importance of urban air defence, continue to promote the integration of urban construction and urban air defence, ensure that the ground and underground construction are not disconnected, and continue to ensure that civil air defence projects and urban construction are synchronized to meet the requirements of urban development as much as possible.

Functional departments must also issue a series of policies to synchronize and rationally plan the urban above-ground buildings and underground civil air defence systems. Only in this way can the interests of various cities be maximized. Modern cities in our country are faced with the threat of various disasters, such as earthquakes, typhoons, fires, and floods. The city's ability to withstand disasters will face a huge test when disasters come.

First of all, cities are densely populated. When disasters occur, disaster prevention and emergency response become more difficult, and people are too late to evacuate, resulting in more casualties. Second, the city's social economy and wealth are dense. The economic loss is huge, and the area of the city is relatively large. After the disaster, there will be a chain reaction of disasters, there will be secondary disasters and additional disasters, and finally, the urban network system will be unified. When the disaster destroys the city, it will cause regional paralysis. , The repair is very difficult.

The civil air defence engineering system is particularly important when faced with urban disasters, whether it is a war or a natural disaster. In the development of the city, the people's safety should be put first, and the people's basic disaster prevention quality education should be strengthened in peacetime. When a disaster strikes, we can calmly follow the instructions of the staff to evacuate to the designated location for evacuation.

Residents must not go their own way. They must always follow the instructions of firefighters to evacuate to the nearest underground parking lot, basement, or open space. Firefighters must also improve their own quality and leadership and organization capabilities and play a leading role in times of crisis. Secondly, study thoroughly the economic losses caused by different disasters and the characteristics and mechanisms of disasters, predict the maintenance and construction of civil air defence in the future, and strive to minimize losses when disasters come and then focus on the construction of urban municipal pipe networks. The municipal pipe network is closely related to civil air defence. Related staff need to regularly investigate and 
maintain the municipal pipe network's problems and dilapidated phenomena, as well as space, engineering, and economic measures. When disasters come, they can effectively prevent the occurrence of additional disasters. The last is to use Scientific and technological means to allow the urban network system to be mixed in series and parallel, and when a disaster strikes, the chain reaction can be minimized.

With the advent of the big data era, intelligent civil air defence construction aims to realize the automation and controllability of the civil air defence command system. Through the trial implementation of Unilumin Intelligent Civil Air Defense High Score Visualization Software, it is possible to carry out comprehensive data statistics of city classification and division, fast-moving and zooming map design, dynamic display of 3D modelling and integrated protection plan in the event of a disaster.

Among the specific measures for the construction of smart air defence in the future, we should scientifically formulate feasible plans, actively cooperate with the pilot construction of smart air defence planning in some cities, strengthen the responsibilities of staff, strengthen supervision and management, and use various channels to introduce innovations. Type talents to ensure that the project can take root. In this way, smart, civil air defence can be implemented in the city, achieve the integration of ground and underground, and contribute to the construction of urban civil air defence.

\section{Conclusion}

At the beginning of 2021, the total mileage of subways in Mainland China has reached 7545.5 kilometres, and 44 cities have opened subways. China is undoubtedly the world's largest subway mileage in a narrow sense. The Chinese subway is a veritable underground Great Wall. Although not all cities currently have the conditions to build subways. However, air-raid shelters, underground parking lots, underground shopping malls, underground passages, and even simple underground shelters in ordinary Chinese cities can be built in accordance with the standards of normal civilian use and wartime air defence.

In the city's development, the construction of civil air defence is a very important link. Civil air defence projects have air defence functions during wars, life functions, and economic functions. They also exert social, economic, and combat readiness benefits in our daily lives. In developing and utilizing urban underground space, we must ensure that the effectiveness of urban civil air defence projects can be achieved when necessary. Therefore, the government must take into account the functions of civil air defence projects and achieve the best of both worlds in the process of urban civil air defence projects. , And actively absorb and learn from the experience of foreign urban civil air defence construction and apply it to domestic urban air defence construction to solve various problems existing in urban civil air defence. And make better and rational use of underground space to promote the common development of social, economic, and social benefits.

In designing urban civil air defence projects, designers must continue to refine the details of the civil air defence projects. Initially, the design must ensure the value of the urban air defence projects. The construction can be carried out as scheduled to make adequate preparations for the needs of the people's livelihood and the benefits of the city's economy when the war comes. At the same time, the government should also send relevant staff to publicize and educate the city people to have this awareness and thinking. Awareness, and have participated in the construction of urban air defence projects and made suggestions for the construction of urban air defence projects. Only in this way can the interests of every citizen be guaranteed.

After the construction of the civil air defence process is completed, we must always follow the functions of the civil air defence project, ensure its comprehensive effectiveness, promote social development in peacetime, and do a good job of sheltering the broad masses of the people in wartime.

Acknowledgements: Thanks to the opinions of experts and scholars in the 2020/2021 China Urban Planning Annual Conference and 2021 China Urban Planning Academic Season, which has further deepened and expanded the paper.

\section{References}

[1] Civil Air Defense Office. (2016). Status and development trend of underground space development and utilization abroad.Civil Air Defense Office of Guangdong Province.

[2] Civil Air Defense Office. (2018). Urban civil air defence projects are also "people's livelihood projects", Yushe County People's Government

[3] Dongmei, G. (2004). Thinking on the Construction of Civil Defense Engineering in China. New Architecture, 5(5), 25.

[4] Hui.W, (2018). The status quo and countermeasures of urban civil air defence engineering construction, Suzhou Civil Air Defense Engineering Quality Supervision Station. 217-218.

[5] Greene, J. C. (1972). The Case for Civil Defense (As Developed Through Systems Analysis). Revised. DEFENSE CIVIL PREPAREDNESS AGENCY WASHINGTON DC.

[6] Li, Y.P (2011). Research on Comprehensive Benefit Evaluation of my country's Urban Civil Air Defense Engineering-Taking Nanjing Metro as an example. Nanjing University of Aeronautics and Astronautics.

[7] Mears, A. L. (1997). Civil-Defence Strategies in the UK. In Defense Conversion Strategies (pp. 391-406). Springer, Dordrecht. 
[8] Sun, X.D (2018). Some thoughts on the construction of intelligent civil air defence information, Nantong Civil Defense Command Information Guarantee Center, Nantong, Jiangsu Province. 286-287.

[9] Sun, X.D (2018). Some thoughts on the construction of intelligent civil air defence information, Nantong Civil Defense Command Information Guarantee Center, Nantong, Jiangsu Province. 286-287

[10] Monroe (2019). Research on the Planning and Construction of Urban Civil Air Defense.

[11] Jie. R.Y. (2011). The status and development trend of foreign underground space development and utilization.The Fourth Design and Research Institute of the General Staff Engineers.

[12] Lu. Z.X. (2019) Analysis of Civil Air Defense Project Construction and Urban Underground Space Development and Utilization.Baoji Civil Air Defense Project Maintenance Management Center, Baoji City, Shanxi Province, 164-165.

[13] Shi, Y., \& Yang, X. (2013). The public transportation system is of high quality in Taiwan. Procedia-Social and Behavioral Sciences, 96, 13501361.

[14] Kaliampakos, D. (2016). Underground development: a springboard to make city life better in the 21st century. Procedia Engineering, 165, 205213.

[15] Kai-wen, Z. H. O. N. G. (2006). Construction and implementation of GIS- Based spatial analysis models for civil air defence engineering. Geomatics and Spatial Information Technology, 29(1), 71.

[16] Yang, J., Li, L., Zhao, K., Wang, P., Wang, D., Sou, I. M., ... \& Liu, P. L. F. (2019). A comparative study of Typhoon Hato and Typhoon Mangkhut (2018)-Their impacts on coastal inundation in Macau. Journal of Geophysical Research: Oceans, 124(12), 9590-9619.

[17] Yanjun, Y. A. N. G., Weihua, J., Dongjun, G., \& Zhilong, C. (2002). Investigation on the theory of general planning of urban civil defence engineering. Underground Space, 22(1), 79-82.

[18] Zhang, D.X. (2018). Some thoughts on the construction of "smart air defence", Guangdong Provincial Civil Air Defense Office.

[19] ZIARI, K. (2001). PLANNING FOR CIVIL DEFENSE AND URBAN SHELTER. 